\title{
Autolysis of Clostridium acetobutylicum ATCC 824
}

\author{
Christian Croux, Bruno Canard, Gérard Goma and Philippe Soucaille*
}

Département de Génie Biochimique et Alimentaire, Unité Associée du Centre National de la Recherche Scientifique no. 544, Institut National des Sciences Appliquées, Avenue de Rangueil, F-31077 Toulouse Cedex, France

(Received 12 November 1991; accepted 14 January 1992)

\begin{abstract}
The optimum conditions for autolysis of Clostridium acetobutylicum ATCC 824 were determined. Autolysis was optimal at pH 6.3 and $55^{\circ} \mathrm{C}$ in $0.1 \mathrm{M}$-sodium acetate/phosphate buffer. The ability of cells to autolyse decreased sharply at the end of the exponential phase of growth. Lysis was stimulated by monovalent cations and compounds that complex divalent cations, and inhibited by divalent cations. The autolysin of $C$. acetobutylicum, which was mainly cytoplasmic, was purified to homogeneity and characterized as a muramidase. The enzyme was identical to the extracellular muramidase in terms of $M_{\mathrm{r}}$, isoelectric point and $\mathrm{NH}_{2}$-terminal amino acid sequence. The autolysin was inhibited by lipoteichoic acids and cardiolipin but not by phosphatidylethanolamine and phosphatidylglycerol. A mechanism of regulation and fixation involving lipoteichoic acid, cardiolipin and divalent cations is proposed.
\end{abstract}

\section{Introduction}

The anaerobic spore-forming Gram-positive bacterium Clostridium acetobutylicum is a well-known producer of acetone and butanol, two solvents of industrial interest (for a review see Jones \& Woods, 1986). Butanol is highly toxic for the micro-organism (Soucaille et al., 1987) and during the later stages of the fermentation degeneration and partial lysis of the cells are observed. A pleiotropic autolysin-defective mutant that produces decreased amounts of autolysin and was less sensitive to autolytic enzyme has also been reported to be more resistant to cell degeneration in the presence of butanol (Allcock et al., 1981; Van Der Westhuisen et al., 1982).

The physiological and physico-chemical conditions leading to the autolysis of $C$. acetobutylicum have not been extensively studied. Furthermore, only one enzyme involved in the autolysis of a solvent-producing Clostridium has been partially purified and characterized (Yoshino et al., 1982). In order to investigate the regulatory mechanism that controls the autolytic enzymes of $C$. acetobutylicum, we have undertaken a study of the conditions promoting or inhibiting cell lysis and a purification of the autolytic enzyme(s) involved.

\footnotetext{
- Author for correspondence. Present address: Department of Chemical Engineering, Northwestern University, 2145 Sheridan Road, Evanston, IL 60208, USA; tel. (708) 491 2776; fax (708) 491 3728.
}

\section{Methods}

Organism and culture conditions. C. acetobutylicum ATCC 824 was obtained from the American Type Culture Collection. The strain was grown at $35^{\circ} \mathrm{C}$ and pH 4.8, in a 2 litre (SGI, France) fermenter stirred at 200 r.p.m., using the synthetic medium previously described (Soni $e t$ al., 1987). The fermenter was inoculated with a $1 / 10$ th volume of an early exponential phase culture, previously subcultured in the same medium.

For cell fractionation and autolysin purification, the fermentation broth was collected at the end of the exponential phase of growth $(10 \mathrm{~h}$ of culture), centrifuged $\left(15 \mathrm{~min}, 15000 \mathrm{~g}, 4^{\circ} \mathrm{C}\right)$ and the pellet resuspended in 0.01 M-sodium acetate buffer, $\mathrm{pH} 4$.

Cell fractionation. Cells were disrupted by three passages through a French press at 20000 p.s.i. (about $138 \mathrm{MPa}$ ). Unbroken cells were removed by centrifugation $\left(10 \mathrm{~min}, 1000 \mathrm{~g}, 4^{\circ} \mathrm{C}\right)$. Cell walls were pelleted $\left(12000 \mathrm{~g}, 20 \mathrm{~min}, 4^{\circ} \mathrm{C}\right)$, washed once and resuspended in $0.01 \mathrm{M}$-sodium phosphate buffer, $\mathrm{pH} 6$ (cell-wall fraction). Membranes were recovered from the supernatant by high-speed centrifugation $\left(220000 \mathrm{~g}, 2 \mathrm{~h}, 4^{\circ} \mathrm{C}\right)$ and resuspended in $0.01 \mathrm{M}$-sodium acetate buffer, pH 4 (membrane fraction). The supernatant from this centrifugation served as the cytoplasmic fraction.

Autolytic enzyme purification. The cytoplasmic fraction and the product of autolysis of the cell-wall fraction after $7 \mathrm{~h}$ at $30^{\circ} \mathrm{C}$ were combined.

(i) Ultrafiltration. The solution was concentrated to $9 \mathrm{ml}$ and dialysed against 1 litre of $0.02 \mathrm{M}$-sodium acetate buffer, $\mathrm{pH} 5 \cdot 2$, using an ultrafiltration device (H1 P10 Amicon, cut-off $M_{\mathrm{r}}$ 10000), and filtered through a $0.2 \mu \mathrm{m}$ membrane (Sartorius); $8 \mathrm{ml}$ of filtrate were recovered and used as the crude enzyme preparation for the next steps of purification.

(ii) Column chromatography. All the purification steps were done on a Pharmacia FPLC system. Crude enzyme solution (8 ml, $1640 \mathrm{U}$ ) was applied to a prepacked Mono Q HR 10/10 column $(1 \times 10 \mathrm{~cm})$, a 
strong anion-exchanger, previously equilibrated with $0.02 \mathrm{M}$-sodium acetate buffer, $\mathrm{pH} 5 \cdot 2$. Elution was at a flow rate of $8 \mathrm{ml} \mathrm{min}^{-1}$ using a linear $\mathrm{NaCl}$ gradient $(0$ to $0.3 \mathrm{M}$ over $30 \mathrm{~min})$. Fractions $(8 \mathrm{ml})$ were collected and tested for autolytic activity as described below.

The autolytic-positive fractions from the anion-exchange chromatography were concentrated by ultrafiltration through a Centriprep-10 concentrator (Amicon, cut-off $M_{\mathrm{r}} 10000$ ) to a final volume of $20 \mathrm{C} \mu \mathrm{l}$ and applied to a Superose $12 \mathrm{HR} 10 / 30$ column $(1 \times 30 \mathrm{~cm})$ previously equilibrated with $0 \cdot 1 \mathrm{M}$-sodium acetate buffer, $\mathrm{pH} 5$. The column was eluted with one bed volume of the same buffer at a flow rate of $0.3 \mathrm{ml} \mathrm{min}{ }^{-1}$. Fractions $(0.5 \mathrm{ml})$ were collected and tested for autolytic activity.

Assay of autolytic enzyme activity. The standard assay was done at $\mathrm{pH} 4$, in $0.1 \mathrm{M}$-sodium acetate buffer, by measuring the decrease of turbidity of a purified cell wall suspension, as previously described for the extracellular lytic enzyme (Croux et al., 1992). One Unit (U) $\mathrm{ml}^{-1}$ of lytic activity was defined as the amount of enzyme per ml which reduces the turbidity of a purified cell-wall suspension by $0.001 \mathrm{OD}_{450} \mathrm{~min}^{-1}$ at $35^{\circ} \mathrm{C}$.

For the fractionation study, the autolytic activity was measured using $5 \mu \mathrm{g}$ [ methyl $^{3} \mathrm{H}$ ]choline-labelled, purified cells walls of $C$. acetobutylicum NCIB 8052 (Croux et al., 1992) in a total volume of $250 \mu \mathrm{l}$. In some cases the $250 \mu \mathrm{l}$ volume also contained detergent (deoxycholate or Brij at $\mathbf{0 . 1 \%}$ final concentration). One Unit of lytic activity was defined as the amount of enzyme that solubilized $1 \mu \mathrm{g}$ cell wall $\min ^{-1}$ at $35^{\circ} \mathrm{C}$

Protein concentration was estimated by the Lowry method with bovine serum albumin as the standard.

Inhibition of the autolytic enzyme by phospholipids and lipoteichoic acids. Phospholipids were first dissolved in methanol as a 100-fold concentrated solution before being added to the reaction mixture. Inhibition values were obtained by reference to a control run in the presence of $1 \%(\mathrm{v} / \mathrm{v})$ methanol. Lipoteichoic acids were dissolved in water.

Molecular mass determination. The molecular mass of the autolytic enzyme was determined by SDS-PAGE in a Phast-Gel 8-25\% gradient using the Pharmacia Phast-System.

Samples were previously heated at $100^{\circ} \mathrm{C}$ for $5 \mathrm{~min}$ in the presence of $2.5 \%(w / v)$ SDS. Protein bands were stained with silver nitrate. Calibration proteins ranging in $M_{\mathrm{r}}$ from 14400 to 94000 (low molecular mass calibration kit; Pharmacia) were used for the estimation of the $M_{\mathrm{r}}$ of the lytic enzyme. To estimate the native $M_{\mathrm{r}}$ of the enzyme, gelfiltration chromatography was carried out on a Superose 12 HR 10/30 column calibrated with proteins of known molecular mass as standards (low molecular mass gel-filtration calibration kit; Pharmacia).

Isoelectric point determination. Analytical isoelectric focusing PAGE was performed in a Phast-Gel IEF 3-9 gradient using the Pharmacia Phast-System. Protein bands were stained with silver nitrate. The isoelectric point of the autolysin was determined with broad-range standard protein markers (Pharmacia) ranging from pI 3 to 10.

$\mathrm{NH}_{2}$-terminal amino acid sequence. The $\mathrm{NH}_{2}$-terminal amino acid sequence of lytic enzyme was determined by stepwise Edman degradation (Croux et al., 1992) with a gas-phase sequencer (Applied Biosystems, model 470A) and high pressure liquid chromatography identification of the phenylthiohydantoin derivatives of amino acids obtained from the sequencer (Applied Biosystems model 120A).

Autolysis procedures. Cells were harvested by centrifugation $\left(12000 \mathrm{~g}, 2 \mathrm{~min}, 4^{\circ} \mathrm{C}\right)$ and after the supernatant fluid had been discarded, residual growth medium was removed with cotton tips. The unwashed pellet was then diluted to an initial $\mathrm{OD}_{620}$ of 1 into preincubated $\left(35^{\circ} \mathrm{C}\right) 0 \cdot 1 \mathrm{M}$-sodium phosphate buffer. The decrease in optical density was monitored at $35^{\circ} \mathrm{C}$ as a function of time. The firstorder rate constant of autolysis, $k\left(\mathrm{~min}^{-1}\right)$, was calculated from the slope of the $\log \left(\mathrm{OD}_{620}\right)$ curve as a function of time.

Liberation of reducing sugars and free amino groups. Liberation of reducing sugars during the hydrolysis of cell walls was measured in heat-treated samples $\left(3 \mathrm{~min}\right.$ at $\left.100^{\circ} \mathrm{C}\right)$ by the method of Park \& Johnson (1949) as modified by Thompson \& Shockman (1968). Liberation of free amino groups was measured in heat-treated samples $\left(3 \mathrm{~min}\right.$ at $100^{\circ} \mathrm{C}$ ) by the method of Ghuysen et al. (1968).

Specificity of the autolysin. Purified cell walls $\left(2 \mathrm{mg} \mathrm{m}^{-1}\right)$ were digested by the autolysin $\left(10 \mathrm{U} \mathrm{ml}^{-1}\right)$ at $30^{\circ} \mathrm{C}$ for $9 \mathrm{~h}$. The reducing sugars liberated into the supernatant were reduced with $\mathrm{NaBH}_{4}$ $\left(10 \mathrm{mg} \mathrm{ml}^{-1}\right)$ at $\mathrm{pH} 9$ in $0.1 \mathrm{M}$-borate buffer. The sample was dried in vacuo, washed three times with methanol and hydrolysed with $6 \mathrm{M}-\mathrm{HCl}$ at $100^{\circ} \mathrm{C}$ for $4 \mathrm{~h}$. After three washes in methanol the sample was dissolved in 0.1 M-citrate buffer and analysed on a Biotronic C200 amino acid analyser.

Electron microscopy. Bacterial morphology of autolysing cells was inspected after fixing with $2 \%$ glutaraldehyde (pH 7) for $10 \mathrm{~min}$ at room temperature. Samples were then applied as a thin film to 200 mesh Formvar-coated copper grids and briefly exposed to $2 \%(w / v)$ potassium phosphotungstic acid (pH 6.8).

Materials. The chemicals used were from Sigma except [methyl${ }^{3} \mathrm{H}$ ]choline from Amersham.

\section{Results}

C. acetobutylicum cells taken from the exponential phase of growth spontaneously autolysed when they were suspended in sodium phosphate buffer, pH 6.3 (Fig. 1). Concomitantly, UV-absorbing material was released. The autolysis of $C$. acetobutylicum followed first-order kinetics. Electron microscopy of autolysing cells revealed that digestion of the cell walls occurred first at the polar regions (Fig. 2).

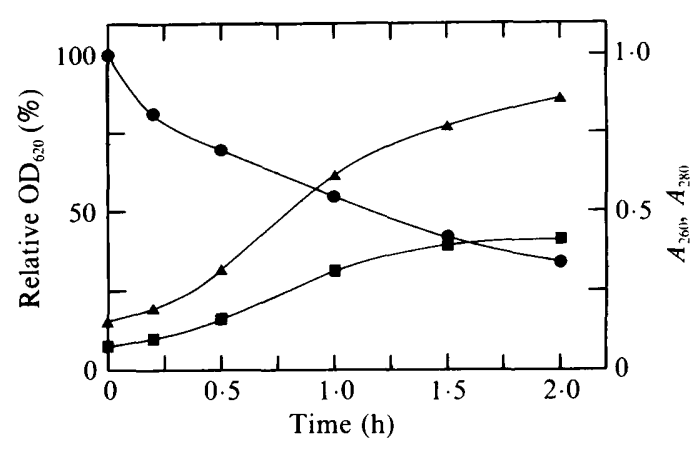

Fig. 1. Kinetics of autolysis of C. acetobutylicum ATCC 824. Autolysis of exponential phase cells was assayed in $0 \cdot 1 \mathrm{M}$-sodium phosphate, $\mathrm{pH} 6.3$, as loss of $\mathrm{OD}_{620}$ of the suspension (๑) and increase of absorbance of supernatants at $260(\Delta)$ and $280(\mathbb{D}) \mathrm{nm}$. 

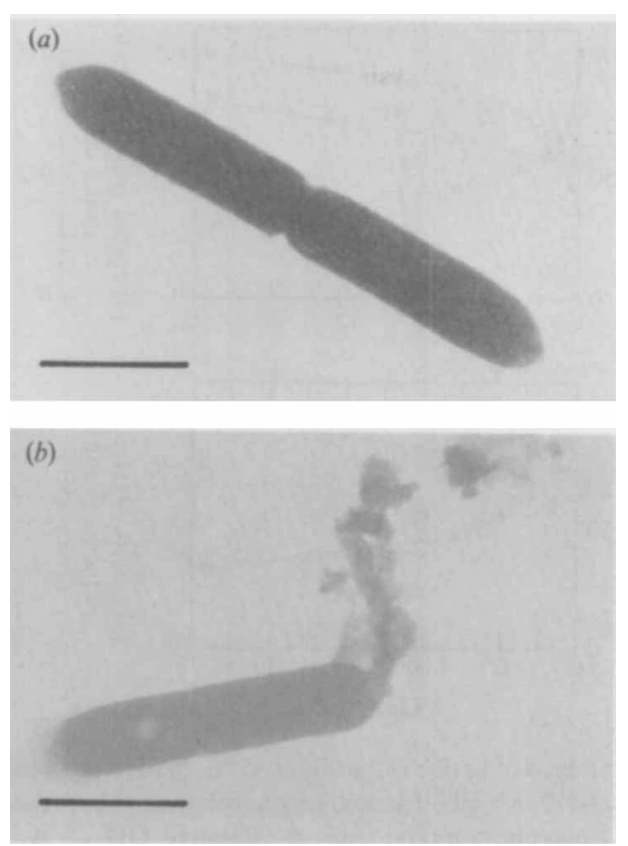

Fig. 2. Transmission electron micrograph of $C$. acetobutylicum ATCC 824. Cells were fixed and postfixed as described in Methods. (a) Control exponential phase cells; (b) exponential phase cells harvested and transferred to $0 \cdot 1 \mathrm{M}$-sodium phosphate, $\mathrm{pH} \mathrm{6 \cdot 3}$, at $35^{\circ} \mathrm{C}$ for $1 \mathrm{~h}$. Bars, $1 \mu \mathrm{m}$.

\section{Effect of $p H$, temperature and phase of growth}

The initial rate of autolysis was dependent upon the $\mathrm{pH}$ of the sodium acetate/phosphate buffer; the optimum was at $\mathrm{pH} 6 \cdot 3$.

The initial rate of autolysis was also clearly dependent on the temperature at which the cells were incubated with an optimum at $55^{\circ} \mathrm{C}$. The Arrhenius law held true between 20 and $45^{\circ} \mathrm{C}$, indicating competition between kinetic activation and denaturation of the enzyme system at higher temperature. The activation energy for the autolysis of cells was calculated to be $34 \mathrm{~kJ} \mathrm{~mol}^{-1}$.

The rate constant of autolysis $(k)$ reached a maximum for cells from the end of the exponential phase of growth, a minimum for cells from the stationary phase and increased again in the lysis phase (Fig. 3).

\section{Effect of different ions and chelating agents}

All the monovalent cations used (except $\mathrm{NH}_{4}^{+}$) increased the rate constant of autolysis at concentrations higher than $0.1 \mathrm{M}$ (Table 1). On the other hand, at concentrations higher than $10^{-4} \mathrm{M}$, all the divalent cations tested (except $\mathrm{Mn}^{2+}$ ) inhibited the autolysis of C. aceto-

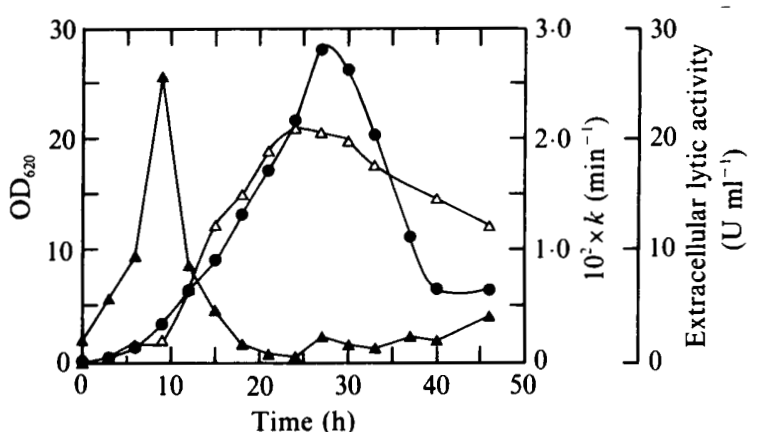

Fig. 3. Autolysis of cells and extracellular lytic activity during different stages in the growth cycle. $\bullet, \mathrm{OD}_{620} ; \Delta$, autolysis constant, $k ; \Delta$, extracellular lytic activity.

Table 1. Effect of monovalent cations on the autolysis of C. acetobutylicum ATCC 824

Cells were harvested at the end of the exponential phase of growth and autolysis was assayed in $0.1 \mathrm{M}$-sodium phosphate, $\mathrm{pH} 6.3$, as loss of $\mathrm{OD}_{620}$.

\begin{tabular}{lccc}
\hline \hline Cation* & $\begin{array}{c}\text { Concn } \\
(\mathrm{M})\end{array}$ & $\begin{array}{c}10^{3} \times k \\
\left(\mathrm{~min}^{-1}\right)\end{array}$ & $\begin{array}{c}\text { Relative } \\
\text { rate (\%) }\end{array}$ \\
\hline None & & $5.1 \pm 0.45$ & 100 \\
$\mathrm{Na}^{+}$ & 0.1 & $5.3 \pm 0.5$ & 104 \\
& 0.2 & $10.6 \pm 0.6$ & 208 \\
& 0.3 & $13.8 \pm 0.7$ & 271 \\
$\mathrm{~K}^{+}$ & 0.1 & $5.2 \pm 0.5$ & 102 \\
& 0.2 & $9.5 \pm 0.6$ & 186 \\
& 0.3 & $12.5 \pm 0.6$ & 245 \\
$\mathrm{NH}_{4}^{+}$ & 0.1 & $5.05 \pm 0.5$ & 99 \\
& 0.2 & $5.1 \pm 0.4$ & 100 \\
& 0.3 & $5.6 \pm 0.5$ & 110 \\
\hline \hline
\end{tabular}

$* \mathrm{Cl}^{-}$was the anion in all the experiments.

butylicum (Table 2). Chelating agents, at a concentration of $5 \times 10^{-3} \mathrm{M}$ increased the rate constant of autolysis by $80 \%$ for EDTA, $70 \%$ for EGTA and $120 \%$ for citrate. The effect of EDTA, at a concentration of $5 \times 10^{-3} \mathrm{M}$, could be completely overcome by the addition of $5 \times 10^{-2} \mathrm{M}$ (final concentration) $\mathrm{MgSO}_{4}$.

\section{Effect of amino acids, amino sugars and amino alcohols}

Among the amino acids and amino sugars found in the peptidoglycan of $C$. acetobutylicum only glucosamine (acetylated or not) inhibited cell autolysis $(20 \%$ inhibition at a concentration of $1 \mathrm{~mm})$. At a concentration of $0.3 \mathrm{M}$ both ethanolamine (relative constant rate of $270 \%$ ) and choline (relative constant rate of $280 \%$ ) activated cell autolysis. 
Table 2. Effect of divalent cations on the autolysis of C. acetobutylicum ATCC 824

Cells were harvested at the end of the exponential phase of growth and autolysis was assayed in $0.1 \mathrm{M}$-sodium phosphate, $\mathrm{pH} 6.3$, as loss of $\mathrm{OD}_{620}$.

\begin{tabular}{lllr}
\hline \hline Cation* & $\begin{array}{c}\text { Concn } \\
(\mathrm{M})\end{array}$ & \multicolumn{1}{c}{$\begin{array}{c}10^{3} \times k \\
\left(\mathrm{~min}^{-1}\right)\end{array}$} & $\begin{array}{r}\text { Relative } \\
\text { rate }(\%)\end{array}$ \\
\hline None & & $5 \cdot 1 \pm 0 \cdot 45$ & 100 \\
$\mathrm{Cu}^{2+}$ & $10^{-5}$ & $1 \cdot 06 \pm 0 \cdot 12$ & 21 \\
& $10^{-4}$ & 0 & 0 \\
$\mathrm{Zn}^{2+}$ & $10^{-3}$ & 0 & 0 \\
& $10^{-5}$ & $3 \cdot 7 \pm 0 \cdot 39$ & 73 \\
& $10^{-4}$ & $2 \cdot 4 \pm 0 \cdot 3$ & 47 \\
$\mathrm{Fe}^{2+}$ & $10^{-3}$ & $0 \cdot 5 \pm 0 \cdot 1$ & 10 \\
& $10^{-5}$ & $4 \cdot 8 \pm 0 \cdot 5$ & 94 \\
& $10^{-4}$ & $4 \cdot 0 \pm 0 \cdot 4$ & 79 \\
$\mathrm{Mg}^{2+}$ & $10^{-3}$ & $2 \cdot 0 \pm 0 \cdot 18$ & 45 \\
& $10^{-5}$ & $5 \cdot 1 \pm 0 \cdot 5$ & 100 \\
& $10^{-4}$ & $4 \cdot 2 \pm 0 \cdot 4$ & 82 \\
$\mathrm{Ca}^{2+}$ & $10^{-3}$ & $2 \cdot 6 \pm 0 \cdot 3$ & 51 \\
& $10^{-5}$ & $5 \cdot 15 \pm 0 \cdot 5$ & 101 \\
& $10^{-4}$ & $5 \cdot 1 \pm 0 \cdot 5$ & 100 \\
$\mathrm{Mn}^{2+}$ & $10^{-3}$ & $3 \cdot 4 \pm 0 \cdot 3$ & 67 \\
& $10^{-5}$ & $5 \cdot 15 \pm 0 \cdot 45$ & 101 \\
& $10^{-4}$ & $5 \cdot 1 \pm 0 \cdot 5$ & 100 \\
& $10^{-3}$ & $4 \cdot 6 \pm 0 \cdot 5$ & 90 \\
\hline \hline
\end{tabular}

* $\mathrm{SO}_{4}^{2-}$ was the anion in all the experiments.

Table 3. Distribution of autolytic activity in different cell fractions

Activity for each fraction is given as a percentage of the total activity and was measured by solubilization of labelled cell walls in $0 \cdot 1$ M-sodium acetate buffer, $\mathrm{pH} 4$.

\begin{tabular}{lccc}
\hline \hline Fraction & $\begin{array}{c}\text { Activity } \\
(\%)\end{array}$ & $\begin{array}{c}\text { Activation by } \\
\mathbf{0} \cdot 1 \% \text { Brij } \\
(\%)\end{array}$ & $\begin{array}{c}\text { Activation by } \\
\mathbf{0} \% 1 \% \text { deoxycholate } \\
(\%) \dagger\end{array}$ \\
\hline Cell wall & $34 \pm 12$ & $124 \pm 6$ & $110 \pm 7$ \\
Cytoplasm & $64 \pm 15$ & $116 \pm 8$ & $117 \pm 6$ \\
Membrane & $2 \pm 2$ & $115 \pm 10$ & $120 \pm 11$ \\
\hline \hline
\end{tabular}

* Relative activities with and without detergent for each fraction. Activities were measured by solubilization of labelled cell walls in 0.1 M-sodium acetate buffer, pH 4.

$\dagger$ Relative activities with and without detergent for each fraction. Activities were measured by solubilization of labelled cell walls in 0.1 M-sodium phosphate buffer, $\mathrm{pH}$ 6.5.

\section{Distribution of autolytic enzyme(s) in different cell fractions}

In order to purify the autolytic enzyme(s), their localization was first examined after breakage of the cells at pH 4 with a French press. Only small amounts of autolytic activity were detected in the membrane

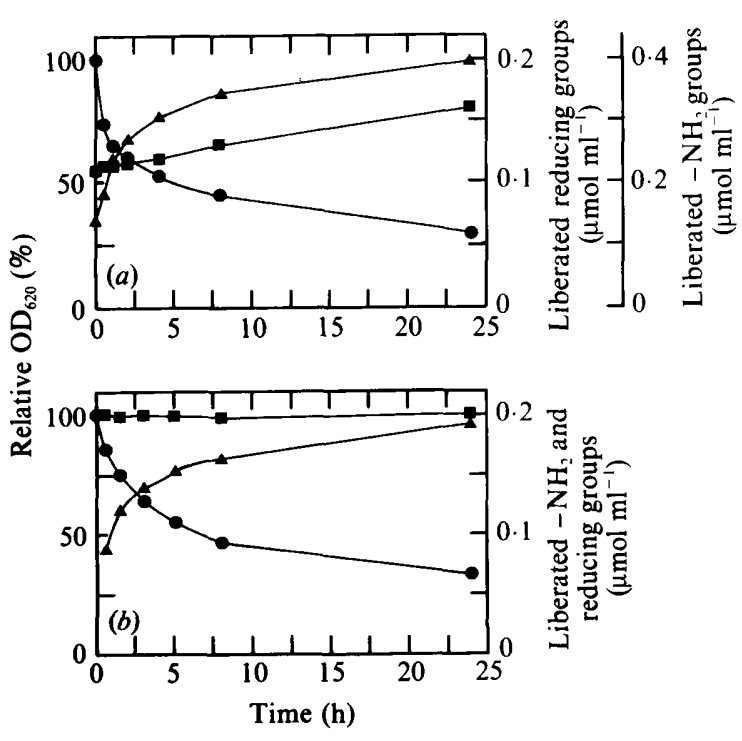

Fig. 4. Autolysis of native cell walls at $35^{\circ} \mathrm{C}$. Native cell walls $(20 \mathrm{mg})$ were suspended in $5 \mathrm{ml} \mathrm{0.1} \mathrm{M}$-sodium phosphate, $\mathrm{pH} 6$, without $(a)$ and with (b) 1 mM-phosphoramidone. $\bullet$, Relative $\mathrm{OD}_{620} ; \Delta$, liberated reducing groups; $\boldsymbol{\square}$, liberated $-\mathrm{NH}_{2}$ groups.

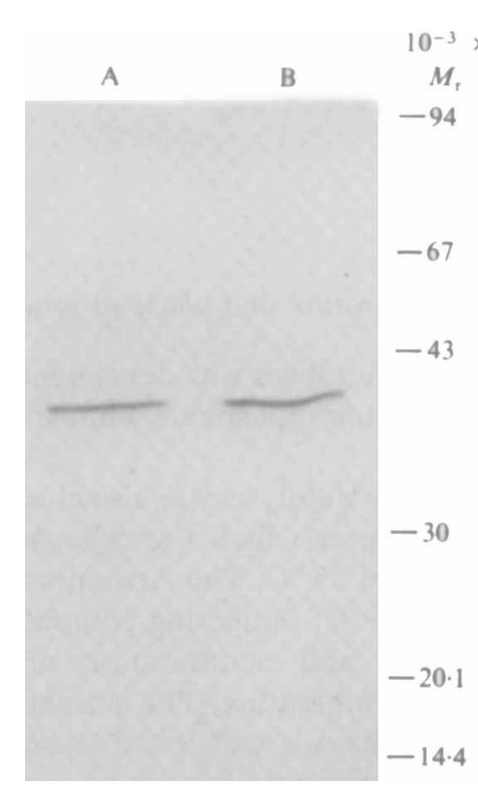

Fig. 5. SDS-PAGE of the autolysin (lane A) and the extracellular muramidase (lane B) of C. acetobutylicum ATCC 824.

fraction, most activity being either cytoplasmic or associated with the cell wall (Table 3). Measurement of autolytic activity in the presence of deoxycholate or Brij, detergents that suppress inhibition of the autolysin by lipoteichoic acid, led to only slightly increased activity in the different fractions. 


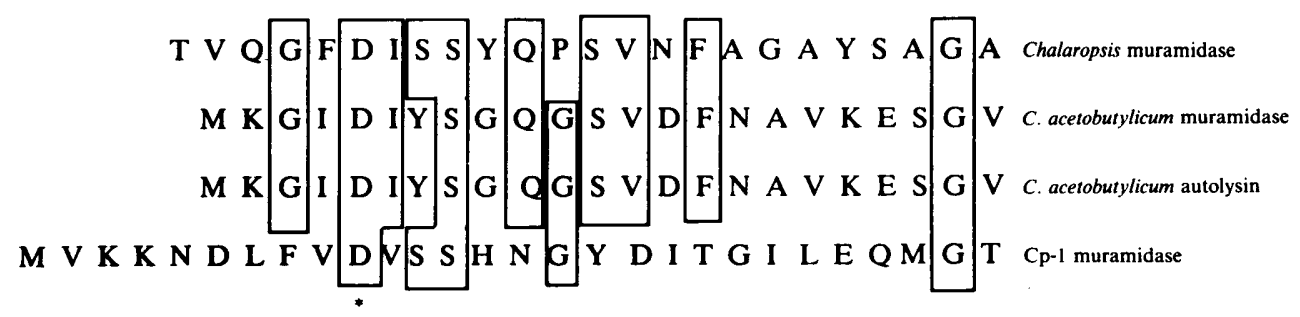

Fig. 6. Comparison of $\mathrm{NH}_{2}$-terminal amino acid sequences of the autolysin from $C$. acetobutylicum and muramidases from $C$. acetobutylicum (Croux et al., 1992), Chalaropsis (Felch et al., 1975) and Cp-1 phage of S. pneumoniae (E. Garcia et al., 1988). * Amino acid involved in the active site of the Chalaropsis muramidase.

Table 4. Extraction of the autolysin from the cell wall

Native cell walls were used at a concentration of $10 \mathrm{mg} \mathrm{ml}^{-1}$ in all experiments.

\begin{tabular}{|c|c|c|c|c|c|c|c|c|c|c|c|c|c|}
\hline \multirow{2}{*}{$\begin{array}{l}\text { Activity } \\
\text { liberated } \\
\text { into the } \\
\text { supernatant }\end{array}$} & \multirow{2}{*}{$\begin{array}{c}\mathrm{NaOH} \\
\text { treatment } \\
(+200 \mu \mathrm{g} \\
\left.\mathrm{BSA} \mathrm{ml}^{-1}\right)\end{array}$} & \multirow{2}{*}{$\begin{array}{c}\mathrm{LiCl} \\
\text { treatment } \\
(5 \mathrm{M})^{*}\end{array}$} & \multicolumn{6}{|c|}{$\begin{array}{l}\text { Treatments at different } \mathrm{pH} \\
\left(90 \text { min incubation at } 4{ }^{\circ} \mathrm{C}\right)\end{array}$} & \multicolumn{3}{|c|}{$\begin{array}{c}\text { Ultrasonic } \\
\text { treatment } \\
\text { (pH 6) }\end{array}$} & \multicolumn{2}{|c|}{$\begin{array}{c}\text { Cell wall } \\
\text { autolysis } \\
\left(7 \mathrm{~h}, 30^{\circ} \mathrm{C}\right)\end{array}$} \\
\hline & & & pH 3 & pH 4 & pH 5 & pH 6 & pH 7 & pH 8 & $\begin{array}{c}2 \\
\min \end{array}$ & $\begin{array}{c}15 \\
\min \end{array}$ & $\begin{array}{c}60 \\
\min \end{array}$ & pH 4 & pH 6 \\
\hline $\begin{array}{l}\text { Autolytic } \\
\text { activity } \\
\left(\mathrm{U} \mathrm{ml}^{-1}\right)\end{array}$ & $2 \cdot 5$ & 0 & $1 \cdot 5$ & $1 \cdot 75$ & 1.91 & $2 \cdot 58$ & 4.08 & $4 \cdot 1$ & $2 \cdot 7$ & 2.9 & 5 & 7 & 13 \\
\hline $\begin{array}{c}\text { Specfic } \\
\text { activity } \\
{\left[\mathrm{U}\left(\mathrm{mg} \mathrm{protein}^{-1}\right]\right.}\end{array}$ & 0.22 & 0 & $1 \cdot 2$ & 1.93 & 0.98 & $0 \cdot 33$ & 0.43 & 0.42 & 0.42 & 0.42 & 0.42 & 2 & 1.5 \\
\hline
\end{tabular}

* Activity was measured after dialysis of the supernatant.

Table 5. Purification of the autolysin of C. acetobutylicum ATCC 824

The starting point for purification was a mixture of the cytoplasmic fraction and the cell wall fraction after treatment at $\mathrm{pH} 6$ for $7 \mathrm{~h}$ at $30^{\circ} \mathrm{C}$. Cells were taken from 1.5 litres of a $10 \mathrm{~h}$ culture of $C$. acetobutylicum ATCC 824.

\begin{tabular}{lccccc}
\hline \hline $\begin{array}{c}\text { Purification } \\
\text { step }\end{array}$ & $\begin{array}{c}\text { Total } \\
\text { activity } \\
(\mathrm{U})\end{array}$ & $\begin{array}{c}\text { Protein } \\
(\mathrm{mg})\end{array}$ & $\begin{array}{c}\text { Specific } \\
\text { activity } \\
\left(\mathrm{U} \mathrm{mg}^{-1}\right)\end{array}$ & $\begin{array}{c}\text { Yield } \\
(\%)\end{array}$ & $\begin{array}{c}\text { Purification } \\
(-\mathrm{fold})\end{array}$ \\
\hline $\begin{array}{l}\text { Crude extract } \\
\begin{array}{c}\text { Concentration, } \\
\text { dialysis and }\end{array}\end{array}$ & 1640 & 550 & 3 & 100 & 1 \\
$\begin{array}{c}\text { filtration } \\
\begin{array}{c}\text { Anion-exchange } \\
\text { chromatography }\end{array}\end{array}$ & 1320 & 87 & 15.2 & 80.5 & $5 \cdot 1$ \\
\begin{tabular}{l} 
Gel filtration \\
\hline \hline
\end{tabular} & 620 & 0.094 & 8700 & 50 & 2920 \\
\hline
\end{tabular}

\section{Extraction of autolysins from the cell wall}

Different methods of extraction of the autolytic enzyme(s) were tested (Table 4). Treatment with high concentrations of $\mathrm{LiCl}$ did not release any active autolysins. Treatment with $\mathrm{NaOH}$ in the presence of
Table 6. Bond specificity of the autolysin

\begin{tabular}{lcc}
\hline \hline \multicolumn{1}{c}{ Compound } & $\begin{array}{c}\text { Purified cell walls } \\
\text { solubilized } \\
\text { surified cell walls } \\
\text { by the autolysin* }\end{array}$ \\
\hline Muramic acid & $1 \cdot 2 \pm 0 \cdot 1$ & $0 \cdot 32 \pm 0 \cdot 1$ \\
Muramitol & $0.02 \pm 0.02$ & $0 \cdot 8 \pm 0.2$ \\
Glucosamine & $2 \cdot 2 \pm 0 \cdot 2$ & $2 \pm 0.3$ \\
Glucosaminitol & 0 & 0 \\
Alanine & $3 \pm 0.4$ & $3 \cdot 1 \pm 0.4$ \\
Glutamic acid & $1 \pm 0 \cdot 3$ & $1 \pm 0.2$ \\
Diaminopimelic acid & $1 \pm 0.4$ & $1 \cdot 2 \pm 0.3$ \\
\hline \hline
\end{tabular}

* Solubilized peptidoglycan was reduced with $\mathrm{NaBH}_{4}$ and analysed after hydrolysis as described in Methods.

bovine serum albumin led to only a low recovery of activity, probably due to significant denaturation of the autolysin at high $\mathrm{pH}$.

Although the amount of extracted autolysin after incubation of cell walls at $4{ }^{\circ} \mathrm{C}$ for $90 \mathrm{~min}$ was higher at basic $\mathrm{pH}$, the specific activity of the supernatant was lower than at acid $\mathrm{pH}$. This indicated that the extraction of autolysin was more specific at low pH. Autolysis of 

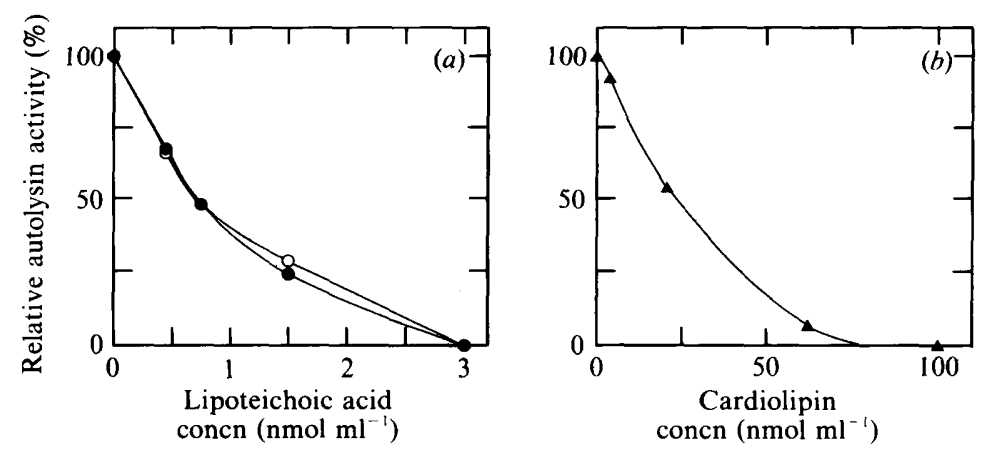

Fig. 7. Inhibition of the autolysin from C. acetobutylicum by lipoteichoic acids and cardiolipin. Autolytic activity $\left(1 \mu \mathrm{g}\right.$ autolysin $\left.\mathrm{ml}^{-1}\right)$ was measured at $35^{\circ} \mathrm{C}$ in $0.1 \mathrm{M}$-sodium acetate buffer, $\mathrm{pH} 4$. $\bullet, S$. faecalis lipoteichoic acid; O, Bacillus subtilis lipoteichoic acid; $\boldsymbol{\Delta}$, cardiolipin. native cell walls for $7 \mathrm{~h}$ at $30^{\circ} \mathrm{C}$ was the most effective treatment for the release of autolysin. As observed above, extraction at $\mathrm{pH} 4$ give the highest specific autolytic activity while the greatest amount of autolysin was released at $\mathrm{pH} 6$.

Nature of the enzyme involved in the autolysis of native cell walls

In sodium acetate/phosphate buffer at $35^{\circ} \mathrm{C}$, the maximum rate of autolysis of native cell walls occurred at pH 6. Autolysis of the walls was accompanied by an increase in the reducing power and in the number of free amino groups liberated (Fig. $4 a$ ). During autolysis of the walls, autolysin $\left(18 \mathrm{U} \mathrm{ml}^{-1}\right)$ and proteinase $\left(41 \mathrm{U} \mathrm{ml}^{-1}\right)$ were also released. The proteolytic activity was due to an acidic metalloprotease inhibited by phosphoramidone (Croux et al., 1990). Autolysis of the walls, in the presence of this specific inhibitor, did not lead to liberation of free amino groups (Fig. $4 b$ ). The rate of liberation of reducing groups was not affected but the rate of wall autolysis was lower. Thus, lysis of the peptidoglycan appeared to result only from the action of a glycosidase(s) and not from $\mathrm{N}$-acetylmuramoyl-Lalanine amidase or endopeptidase activities.

\section{Purification of the autolysin}

The autolysin was purified starting from a mixture of the cytoplasmic fraction and the cell-wall fraction after treatment at $\mathrm{pH}$ 6. After concentration and dialysis, chromatography of the crude enzyme sample through the Mono $Q$ anion-exchanger showed a single peak of autolytic activity. The autolytic enzyme was further purified by gel-permeation chromatography on Superose 12. The enzyme appeared homogeneous when analysed by SDS-PAGE (Fig. 5). The results of the overall purification procedure are presented in Table 5. A 6980fold purification was achieved with a final yield of $42 \%$.

The $M_{\mathrm{r}}$ was calculated to be $41000( \pm 1000)$ (Fig. 5) by SDS-PAGE using standard proteins and $44000( \pm 2000)$ by calibrated Superose 12 column. These results indicate that the autolysin is monomeric. The isoelectric point of the autolysin, estimated by isoelectric focusing, was 3.8 .

\section{$\mathrm{NH}_{2}$-terminal amino acid sequence}

The $\mathrm{NH}_{2}$-terminal amino acid sequence of the autolysin of $C$. acetobutylicum was determined and compared with those of other lytic enzymes. The 23 amino acids of the autolysin showed $100 \%$ similarity with the extracellular muramidase of $C$. acetobutylicum, 39\% with the first 24 amino acids of the muramidase of the fungus Chalaropsis and $18 \%$ with the first 28 amino acids of the muramidase of the Cp-1 bacteriophage of Streptococcus pneumoniae (Fig. 6).

\section{Effect of $p H$}

The autolysin was active over the $\mathrm{pH}$ range $2 \cdot 5-7$ with an optimum at $\mathrm{pH} 4.5$ on boiled native cell walls, 3.5 on SDS-treated walls and 3 on purified cell walls.

\section{Bond specificity}

Cell walls were digested by the autolysin to $75 \%$ of the initial turbidity with a concomitant release of reducing groups. In order to study the bond specificity, digested cell walls were reduced, hydrolysed with $6 \mathrm{M}-\mathrm{HCl}$ and analysed with an automatic amino acid analyser (Table 6). Compared to undigested cell walls, the sample showed a $70 \%$ decrease in muramic acid which was reduced to muramitol, indicating that the autolysin was a muramidase. 
Effect of phospholipids and lipoteichoic acids on autolysin activity

Among the three phospholipids tested, only cardiolipin was inhibitory $(50 \%$ inhibition at a concentration of $20 \mathrm{nmol} \mathrm{ml}^{-1}$ ) (Fig. 7a). Phosphatidylglycerol and phosphatidylethanolamine at concentrations as high as $200 \mathrm{nmol} \mathrm{ml}^{-1}$ had no effect on autolysin activity.

Two lipoteichoic acids, isolated from Bacillus subtilis and Streptococcus faecalis, had an identical inhibitory effect which was much greater than the effect of cardiolipin (Fig. $7 b$ ).

\section{Discussion}

Cells of C. acetobutylicum spontaneously autolysed when they were transferred from culture medium to a buffer solution. This phenomenon is known for many Grampositive (Kawata et al., 1968; Mohan et al., 1965; Ogata \& Hongo, 1974; Shockman et al., 1961) and Gramnegative (Hebeler \& Young, 1975; Leduc \& van Heijenoort, 1980; MacLeod \& Matulat, 1961; Mohan et $a l ., 1965)$ bacteria and is due to the action of autolytic enzyme on the peptidoglycan (Joseph \& Shockman, 1974; Leduc \& van Heijenoort, 1980; Mohan et al., 1965; Wegener et al., 1977).

We purified the autolysin of C. acetobutylicum ATCC 824 to homogeneity and characterized it as a muramidase. The enzyme was identical to the extracellular muramidase (Croux et al., 1992) in term of $M_{\mathrm{r}}$, isoelectric point and $\mathrm{NH}_{2}$-terminal amino acid sequence. A similar result has been suggested for the lytic enzyme of $C$. saccharoperbutylacetonicum (Yoshino et al., 1982). Unlike C. acetobutylicum NCIB 8052 (J. L. Garcia et al., 1988), no amidase activity could be detected either as liberation of $\mathrm{NH}_{2}$ groups during autolysis of native cell walls or after purification of the autolysins. Moreover, in the presence of choline, strain ATCC 824 neither gave rise to the formation of long chains of cells nor was cellular autolysis inhibited, contrary to what has been observed for strain NCIB 8052 (J. L. Garcia et al., 1988) and for C. saccharoperbutylacetonicum (Podvin et al., 1988). Furthermore we were unable to radiolabel the cell wall of strain ATCC 824 with $\left[\right.$ methyl $\left.{ }^{3} \mathrm{H}\right]$ choline, suggesting that this strain does not contain choline in its cell wall contrary to what has been described for strain NCIB 8052.

Most of the C. acetobutylicum ATCC 824 autolysin was cytoplasmic, a lower proportion being associated with the cell walls in contrast to what has been shown for Bacillus subtilis (Brown, 1972) and Streptococcus faecalis (Shockman \& Cheney, 1969), where the enzyme was associated with the cell wall through the teichoic acids.
The amidase of Streptococcus pneumoniae was mainly cytoplasmic (Briese \& Hakenbeck, 1984, 1985), and did not possess any signal peptide, suggesting a special mechanism for its translocation (P. Garcia et al., 1986; E. Garcia et al., 1988). A similar mechanism could exist for the muramidase of $C$. acetobutylicum, as it has been recently shown that this enzyme does not possess a signal peptide (Croux \& Garcia, 1991).

The rate of cellular autolysis had an optimum at pH 6.3, a value close to the one obtained for $C$. saccharoperbutylacetonicum (Ogata \& Hongo, 1974), $C$. perfringens (Williamson \& Ward, 1979) and C. botulinum (Kawata et al., 1968; Kawata \& Takumi, 1971). However, there was an important difference between the optimum pH, close to 6 , for cellular or native cell-wall autolysis and the optimum $\mathrm{pH}$ of 3 for lysis of purified cell walls by the autolysin. Highly acidic cell wall proteins have already been described for numerous Clostridium strains (Sleytr \& Messner, 1983) and could decrease the local $\mathrm{pH}$ near to the cell wall. The fact that the elimination by SDS of protein from boiled native cell wall led to a decrease in the optimum $\mathrm{pH}$ of the autolysin from 4.5 to 3.5 is in agreement with this hypothesis.

The physiological conditions leading to the most effective autolysis were associated with the end of the exponential phase of growth, as has been previously reported for other Gram-positive bacteria (Allcock et al., 1981; Mohan et al., 1965; Ogata \& Hongo, 1974; Shockman et al., 1961). This could be attributed to variations (i) in the amount of cell-wall associated autolysin, (ii) in the sensitivity of the peptidoglycan to the autolysin or (iii) in the inhibition of cell-wall associated autolysin. The first hypothesis is in agreement with the liberation of the autolysin into the extracellular fluid at the end of the exponential phase of growth, a period in which the ability of the cells to autolyse decreased. The second hypothesis could be related to a change in the degree of acetylation of the peptidoglycan, as the muramidase of $C$. acetobutylicum ATCC 824 is active only if the glucidic part of the peptidoglycan is not $N$-acetylated (Croux et al., 1992). The third hypothesis has been confirmed for Streptococcus faecalis (Carson et al., 1981; Sayare et al., 1972) and is associated with change in the amount of lipoteichoic acid.

Monovalent cations such as $\mathrm{Na}^{+}$and $\mathrm{K}^{+}$increase the rate of autolysis at concentration higher than $0 \cdot 1 \mathrm{M}$. Such an effect has already been described for other species of Clostridium (Ogata \& Hongo, 1974) as well as for Streptococcus faecalis (Shockman et al., 1961), a teichoicacid-negative mutant of Staphylococcus aureus (Gilpin et al., 1972), and the Gram-negative bacterium Neisseria gonorrhoeae (Hebeler \& Young, 1975).

In contrast, all the divalent cations tested (except $\mathrm{Mn}^{2+}$ ) inhibited the autolysis of $C$. acetobutylicum. 
Furthermore, autolysis was activated by the addition of compounds that complex divalent cations, e.g. citrate or EDTA. Similar effects have been reported for some Gram-positive (Ogata \& Hongo, 1974) and Gramnegative (Eagon \& Carson, 1965; Elmros et al., 1976; Leduc \& van Heijenoort, 1980) bacteria. The role of complexing agents as well as the role of monovalent cations could be to eliminate divalent cations from the cell wall and/or the plasma membrane. We have shown that in common with several other autolysins (Cleveland et al., 1976), the muramidase of $C$. acetobutylicum is inhibited by cardiolipin and lipoteichoic acid. These compounds are highly negatively charged and lipoteichoic acids are able to bind divalent cations (Hughes et al., 1973). The autolysin of $C$. acetobutylicum is an acidic protein (pI 3.8), negatively charged under the physiological conditions of growth. The autolysin could be inhibited and fixed to lipoteichoic acid and/or cardiolipin by ionic interactions that involve divalent cations. An association between autolysin and particular membrane fractions has already been shown for Streptococcus pneumoniae (Briese \& Hakenbeck, 1985). When cells of C. acetobutylicum are suspended in buffer, the loss of divalent cations associated with the dilution could lead to liberation of part of the autolysin which would no longer be inhibited, and so autolysis could take place. In the presence of monovalent cations or compounds that complex divalent cations, this phenomenon could be amplified. The partial reversibility of autolysis during addition of divalent cations implies that the autolysin remains within the proximity of the site of fixation and regulation, most probably at the external surface of the cytoplasmic membrane. During growth of the microorganism, the liberation of the autolysin into the culture medium could be due to a limiting or at least low concentration of divalent cations.

One of the experimental results is not in agreement with the hypothetical mechanism of regulation proposed: during cell fractionation of the autolysin, only a small portion of the enzyme was found to be associated with the membrane fraction. However, since the breakage of the cells was done with a French press and at a pH close to the isoelectric point of the autolysin, an in vitro redistribution of the enzyme could have occurred. Immunocytology experiments will be needed to further confirm the distribution of the autolysin in vivo.

Currently, biochemical experiments are in progress to study the autolysis profile and the secretion of the autolysin in the presence of excess concentrations of different divalent cations in the culture medium.

The authors would like to thank Dr N. D. Lindley for useful discussions and assistance in improving the English version of this manuscript.

\section{References}

Allcock, E. R., ReIDS, S. J., JoNes, D. T. \& Woods, D. R. (1981). Autolytic activity and an autolysis deficient mutant of Clostridium acetobutylicum. Applied and Environmental Microbiology 42, 929-935.

BRIESE, T. \& HAKENBECK, R. (1984). Influence of lipoteichoic acid and choline on the autolytic enzyme activity of Streptococcus pneumoniae. In Microbial Cell Wall Synthesis and Autolysis, pp. 210-216. Edited by C. Nombela. Amsterdam: Elsevier.

BRIESE, T. \& HAKENBECK, R. (1985). Interaction of the pneumococcal amidase with lipoteichoic acid and choline. European Journal of Biochemistry 146, 417-427.

BRowN, W. C. (1972). Binding and release from cell walls: a unique approach to the purification of autolysins. Biochemical and Biophysical Research Communications 47, 993-996.

Carson, D. D., Pierenger, R. A. \& Daneo-Moore, L. (1981). Effect of cerulenin on cellular autolytic activity and lipid metabolism during inhibition of protein synthesis in Streptococcus faecalis. Journal of Bacteriology 146, 590-604.

Cleveland, R. F., Wicken, A. J., Danko-Moore, L. \& Shockman, G. D. (1976). Inhibition of wall autolysis in Streptococcus faecalis by lipoteichoic acid and lipids. Journal of Bacteriology 126, 192-197.

Croux, C. \& Garcia, J. L. (1991). Sequence of the lyc gene encoding the autolytic lysozyme of Clostridium acetobutylicum ATCC 824: comparison with other lytic enzymes. Gene 104, 25-31.

Croux, C., Paquet, V., Goma, G. \& Soucaille, P. (1990). Purification and characterization of acidolysin an extracellular acidic metalloprotease produced by Clostridium acetobutylicum ATCC 824. Applied and Environmental Microbiology 56, 3634-3642.

Croux, C., Canard, B., Goma, G. \& Soucaille, P. (1992). Purification and characterization of an extracellular muramidase of Clostridium acetobutylicum ATCC 824 that acts on non $N$-acetylated peptidoglycan. Applied and Environmental Microbiology (in the Press).

EAGON, R. G. \& CARsON, K. I. (1965). Lysis of cell walls and intact cells of Pseudomonas aeruginosa by ethylenediamine tetraacetic acid and by lysozyme. Canadian Journal of Microbiology 11, 193-201.

Elmros, T., Burman, L. G. \& Bloom, G. D. (1976). Autolysis of Neisseria gonorrhoeae. Journal of Bacteriology 126, 969-976.

FelCh, J. W., InAGAMI, T. \& HaSH, J. H. (1975). The N,O-diacetylmuramidase of Chaloropsis species. V. The complete amino acid sequence. Journal of Biological Chemistry 250, 3713-3720.

Garcia, P., Garcia, J. L., Garcia, E. \& Lopez, R. (1986). Nucleotide sequence and expression of the pneumococcal autolysin gene from its own promoter in Escherichia coli. Gene 43, 265-272.

Garcia, E., Garcia, J. L., Garcia, P., Arraras, A., SanchezPUelles, J. M. \& Lopez, R. (1988). Molecular evolution of the lytic enzymes of Streptococcus pneumoniae and its bacteriophages. Proceedings of the National Academy of Sciences of the United States of America 85, 914-918.

Garcia, J. L., Garcia, E., Sanchez-Puelles, J. M. \& Lopez, R. (1988). Identification of a lytic enzyme of Clostridium acetobutylicum that degrades choline-containing pneumococcal cell walls. FEMS Microbiology Letters 52, 133-138.

GhuYsen, J. M., TiPPER, D. J. \& STROMinger, J. L. (1968). Enzymes that degrade bacterial cell walls. Methods in Enzymology 8, 685-699.

Gilpin, R. W., Chatterjee, A. N. \& Young, F. E. (1972). Autolysis of microbial cells: salt activation of autolytic enzymes in a mutant of Staphylococcus aureus. Journal of Bacteriology 111, 272-283.

Hebeler, B. H. \& Young, F. E. (1975). Autolysis of Neisseria gonorrhoeae. Journal of Bacteriology 122, 385-392.

Hughes, A. H., HANCOCK, J. C. \& BADDILEY, J. (1973). The function of teichoic acids in cation control in bacterial membranes. Biochemical Journal 132, 83-93.

JoNES, D. T. \& WooDs, D. R. (1986). Acetone-butanol fermentation revisited. Microbiological Reviews 50, 484-524.

JOSEPH, R. \& SHOCKMAN, G. D. (1974). Autolytic formation of protoplasts (autoplasts) of Streptococcus faecalis 9790: release of cell wall, autolysin, and formation of stable autoplasts. Journal of Bacteriology 118, 735-746. 
Kawata, T. \& Takumi, K. (1971). Autolytic enzyme system of Clostridium botulinum. 1. Partial purification and characterization of an autolysin of Clostridium botulinum Type A. Japanese Journal of Microbiology 15, 1-10.

Kawata, T., Takumi, K., Sato, S. \& Yamashita, A. (1968). Autolytic formation of spheroplasts and autolysis of cell walls in Clostridium botulinum type A. Japanese Journal of Microbiology 12, 445-455.

Leduc, M. \& VAN HeIJnNoORT, J. (1980). Autolysis of Escherichia coli. Journal of Bacteriology 142, 52-59.

Macleod, R. A. \& Matulat, T. (1961). Solute requirement for preventing lysis of some marine bacteria. Nature, London 192, 1209-1210.

Mohan, R. R., Kronish, D. P., Pianptti, R. S., Epstein, R. L. \& SCHWARTZ, B. S. (1965). Autolytic mechanism for spheroplast formation in Bacillus cereus and Escherichia coli. Journal of Bacteriology 90, 1355-1364.

Ogata, S. \& Hongo, M. (1974). Lysis induced by sodium ion and its relation to lytic enzyme systems in Clostridium saccharoperbutylacetonicum. Journal of General Microbiology 81, 315-323.

PARK, J. T. \& Johnson, M. J. (1949). A submicro determination of glucose. Journal of Biological Chemistry 181, 149.

Podvin, L., Reysset, G., HUbert, J. \& Sebald, M. (1988). Presence of choline in teichoic acid of Clostridium acetobutylicum N1-4 and choline inhibition of autolytic functions. Journal of General Microbiology 134, 1603-1609.

Sayare, M., DANeo-Moore, L. \& Shockman, G. D. (1972). Influence of macromolecular biosynthesis on cellular autolysis in Streptococcus faecalis. Journal of Bacteriology 112, 337-344.

SHOCKMAN, G. D. \& CHENEY, M. C. (1969). Autolytic system of Streptococcus faecalis. V. Nature of the autolysin-cell wall complex and its relationship to properties of the autolytic enzyme of Streptococcus faecalis. Journal of Bacteriology 98, 1199-1207.

Shockman, G. D., Conover, M. J., Kolb, J. J., Riley, L. S. \& TOENNIEs, D. J. (1961). Lysis of Streptococcus faecalis. Journal of Bacteriology 81, 36-46.

SleytR, U. B. \& Messner, P. (1983). Crystalline surface layers on bacteria. Annual Review of Microbiology 37, 311-339.

Soucaille, P., Jolliff, G., IZARD, A. \& Goma, G. (1987). Butanol tolerance and autobacteriocin production by Clostridium acetobutylicum. Current Microbiology 14, 295-299.

Soni, B. K., Soucaille, P. \& Goma, G. (1987). Continuous acetonebutanol fermentation: a global approach for the improvement in the solvent productivity in synthetic medium. Applied Microbiology and Biotechnology 25, 317-321.

Thompson, J. S. \& Shockman, G. D. (1968). A modification of the Park and Johnson reducing sugar determination suitable for the assay of insoluble materials: its application to bacterial cell walls. Analytical Biochemistry 22, 260-268.

VAN DER Westhuizen, A., Jones, D. T. \& WoOds, D. R. (1982). Autolytic activity and butanol tolerance of Clostridium acetobutylicum. Applied and Environmental Microbiology 44, 1277-1281.

WeGENER, W. S., Hebeler, B. H. \& Morse, S. A. (1977). Cell envelope of Neisseria gonorrhoeae: relationship between autolysis in buffer and the hydrolysis of peptidoglycan. Infection and Immunity 18, 210-219.

Williamson, R. \& WARD, J. B. (1979). Characterization of the autolytic enzymes of Clostridium perfringens. Journal of General Microbiology 114, 349-354.

Yoshino, S., Ogata, S. \& Hayashida, S. (1982). Some properties of autolysin of Clostridium saccharoperbutylacetonicum. Agricultural and Biological Chemistry 46, 1243-1248. 